U.S. Department of the Interior

U.S. Geological Survey

Fish Community Structure in Relation to Environmental Variables Within the Sacramento River Basin and Implications for the Greater Central Valley, California

Water-Resources Investigations Report 00-247

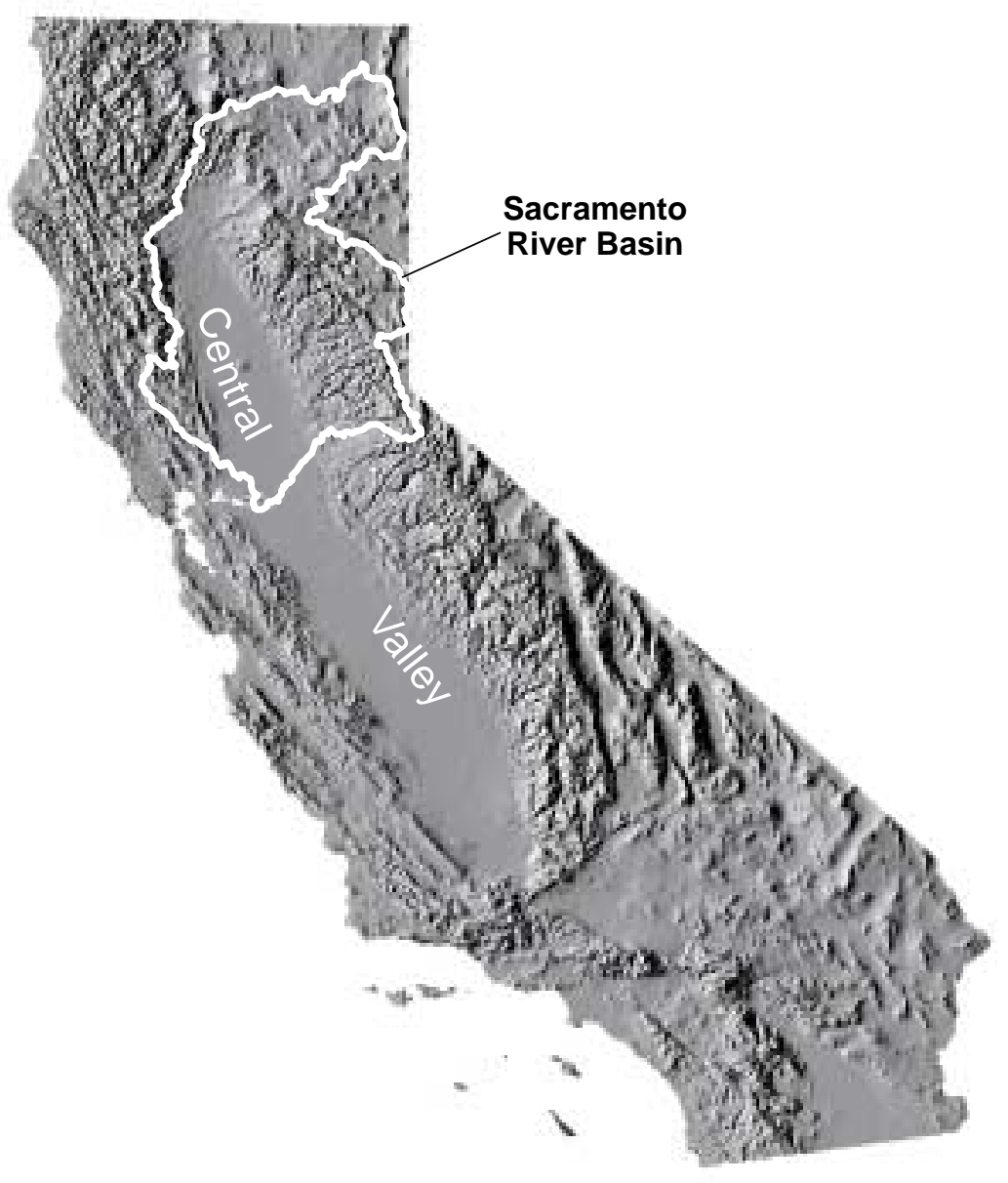


Fish Community Structure in Relation to Environmental Variables within the Sacramento River Basin and Implications for the Greater Central Valley, California

J ason T. May ${ }^{1}$ and Larry R. Brown ${ }^{2}$

U.S. GEOLOGICAL SURVEY

Open-File Report 00-247

ஸे
ஸ̃

${ }^{1}$ California State University Foundation

${ }^{2}$ U.S. Geological Survey 


\section{U.S. DEPARTMENT OF THE INTERIOR \\ BRUCE BABBITT, Secretary}

U.S. GEOLOGICAL SURVEY

Charles G. Groat, Director

The use of firm, trade, and brand names in this report is for identification purposes only and does not constitute endorsement by the U.S. Geological Survey.

For additional information write to:

District Chief

U.S. Geological Survey

Placer Hall, Suite 2012

6000 J Street

Sacramento, CA 95819-6129
Copies of this report can be purchased from:

U.S. Geological Survey

Information Services

Box 25286

Federal Center

Denver, CO 80225 


\section{FOREWORD}

The mission of the U.S. Geological Survey (USGS) is to assess the quantity and quality of the earth resources of the Nation and to provide information that will assist resource managers and policymakers at Federal, State, and local levels in making sound decisions. Assessment of water-quality conditions and trends is an important part of this overall mission.

One of the greatest challenges faced by waterresources scientists is acquiring reliable information that will guide the use and protection of the Nation's water resources. That challenge is being addressed by Federal, State, interstate, and local water-resource agencies and by many academic institutions. These organizations are collecting water-quality data for a host of purposes that include: compliance with permits and water-supply standards; development of remediation plans for specific contamination problems; operational decisions on industrial, wastewater, or watersupply facilities; and research on factors that affect water quality. An additional need for water-quality information is to provide a basis on which regionaland national-level policy decisions can be based. Wise decisions must be based on sound information. As a society we need to know whether certain types of water-quality problems are isolated or ubiquitous, whether there are significant differences in conditions among regions, whether the conditions are changing over time, and why these conditions change from place to place and over time. The information can be used to help determine the efficacy of existing waterquality policies and to help analysts determine the need for and likely consequences of new policies.

To address these needs, the U.S. Congress appropriated funds in 1986 for the USGS to begin a pilot program in seven project areas to develop and refine the National Water-Quality Assessment (NAWQA) Program. In 1991, the USGS began full implementation of the program. The NAWQA Program builds upon an existing base of water-quality studies of the USGS, as well as those of other Federal, State, and local agencies. The objectives of the NAWQA Program are to:

- Describe current water-quality conditions for a large part of the Nation's freshwater streams, rivers, and aquifers.

- Describe how water quality is changing over time.
- Improve understanding of the primary natural and human factors that affect water-quality conditions.

This information will help support the development and evaluation of management, regulatory, and monitoring decisions by other Federal, State, and local agencies to protect, use, and enhance water resources.

The goals of the NAWQA Program are being achieved through ongoing and proposed investigations of 60 of the Nation's most important river basins and aquifer systems, which are referred to as study units. These study units are distributed throughout the Nation and cover a diversity of hydrogeologic settings. More than two-thirds of the Nation's freshwater use occurs within the 60 study units and more than twothirds of the people served by public water-supply systems live within their boundaries.

National synthesis of data analysis, based on aggregation of comparable information obtained from the study units, is a major component of the program. This effort focuses on selected water-quality topics using nationally consistent information. Comparative studies will explain differences and similarities in observed water-quality conditions among study areas and will identify changes and trends and their causes. The first topics addressed by the national synthesis are pesticides, nutrients, volatile organic compounds, and aquatic biology. Discussions on these and other waterquality topics will be published in periodic summaries of the quality of the Nation's ground and surface water as the information becomes available.

This report is an element of the comprehensive body of information developed as part of the NAWQA Program. The program depends heavily on the advice, cooperation, and information from many Federal, State, interstate, Tribal, and local agencies and the public. The assistance and suggestions of all are greatly appreciated.

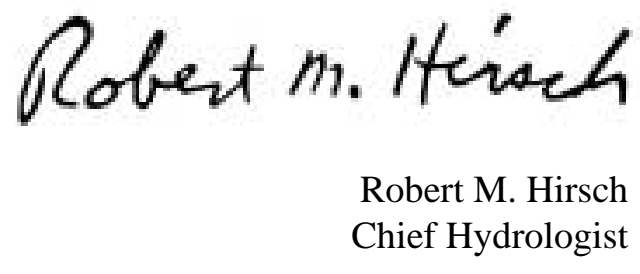




\section{CONTENTS}

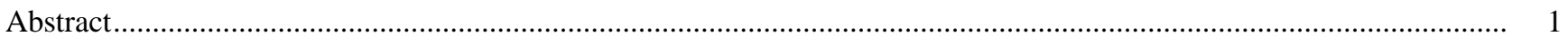

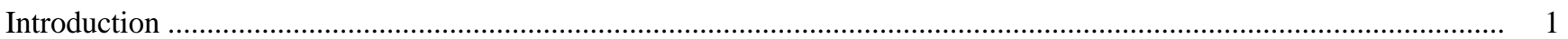

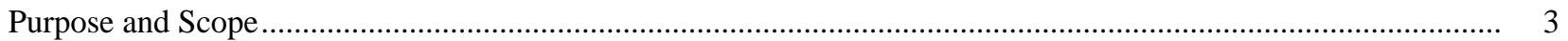

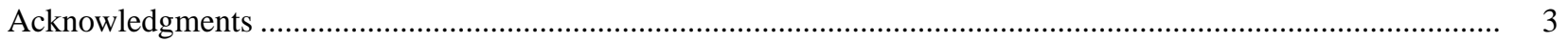

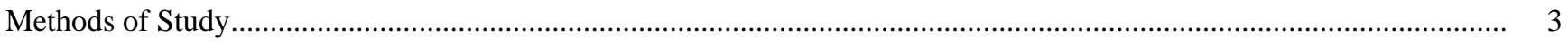

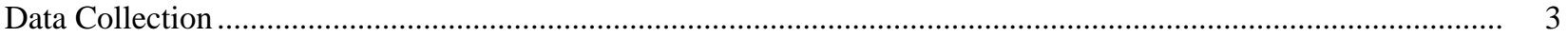

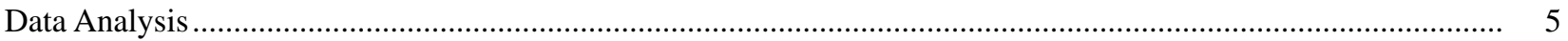

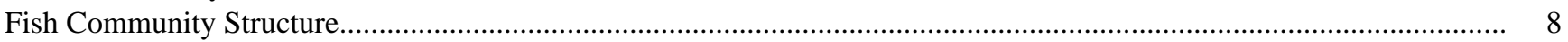

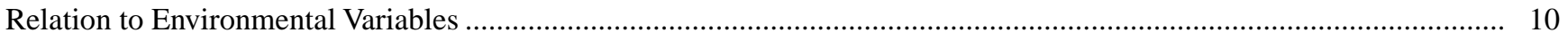

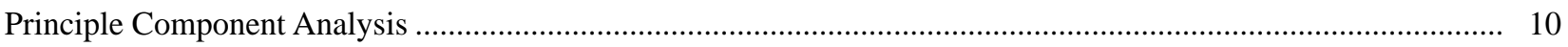

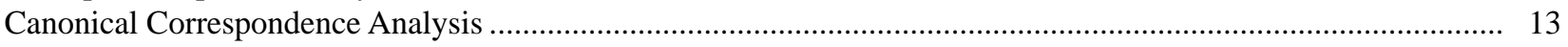

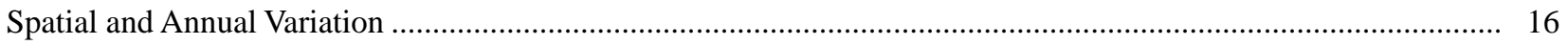

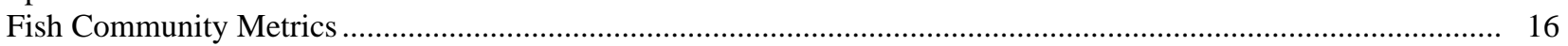

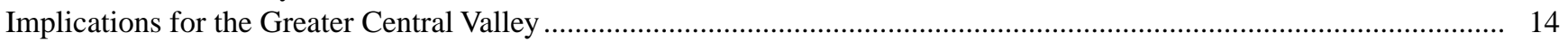

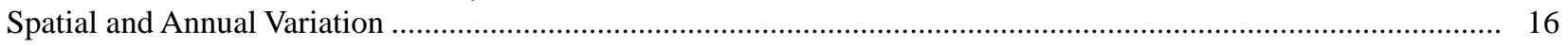

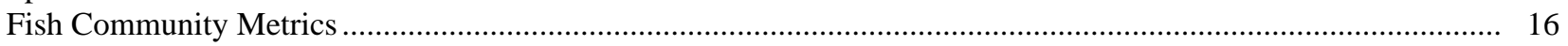

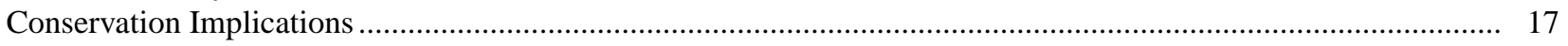

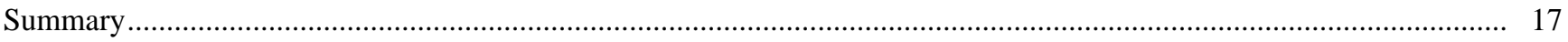

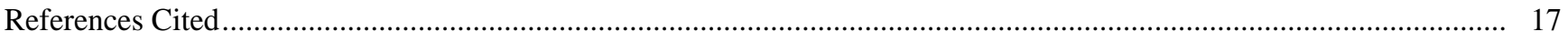

\section{FIGURES}

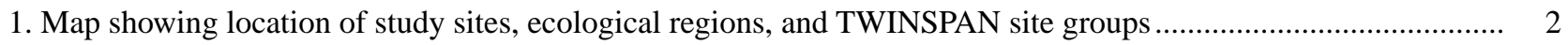

2-4. Graphs showing:

2. Principal component analysis plot of site scores on the first two principal components derived from the environmental variables for sampling sites in the Sacramento River Basin, California

3. Plot of scores on the first two axes from the canonical correspondence analysis for sampling sites in the Sacramento River Basin, California.

4. Plot of detrended correspondence analysis site scores derived from fish species percentage-abundance data from sampling site in the Sacramento River Basin, California

\section{TABLES}

1. Site name, site code, and year(s) sampled for study sites in the Sacramento River Basin, California

2. Common name, species code, scientific name, origin, species group, trophic group, tolerance, and percentage of fish caught in each TWINSPAN site group for all species captured in the Sacramento River Bsin, California

3. Principal component loadings for habitat and water-quality variables from principal component analysis of physical data from 14 of the 22 sites sampled in the Sacramento River Basin, California

4. Mean and range of selected water-quality and habitat variables for the four site groups resulting from TWINSPAN analysis of fish species percentage abundance in the Sacramento River Basin, California

5. Results of canonical correspondence analysis relating fish percentage abundance data to environmental variables in the Sacramento River Basin, California

6. Median and range of selected fish community metrics for TWINSPAN site groups in the Sacramento River Basin, California . 
CONVERSION FACTORS, WATER-QUALITY INFORMATION, VERTICAL DATUM, AND ABBREVIATIONS

\begin{tabular}{rll}
\hline Multiply & By & To obtain \\
\hline & & \\
\hline millimeter $(\mathrm{mm})$ & 0.03937 & inch \\
meter $(\mathrm{m})$ & 3.281 & foot \\
kilometer $(\mathrm{km})$ & 0.6214 & mile \\
\hline
\end{tabular}

Temperature in degrees Celsius $\left({ }^{\circ} \mathrm{C}\right)$, which can be converted to degrees Fahrenheit $\left({ }^{\circ} \mathrm{C}\right)$ as follows:

$$
{ }^{\circ} \mathrm{F}=1.8\left({ }^{\circ} \mathrm{C}\right)+32
$$

\section{Water-Quality Information}

Specific conductance is given in microsiemens per centimeter at 25 degrees Celsius $\left(\mu \mathrm{S} / \mathrm{cm}\right.$ at $\left.25^{\circ} \mathrm{C}\right)$.

\section{Vertical Datum}

Sea level: In this report "sea level" refers to the National Geodetic Vertical Datum of 1929—a geodetic datum derived from a general adjustment of the first-order level nets of the United States and Canada, formerly called Sea Level Datum of 1929.

\section{Abbreviations}

$\begin{array}{ll}\text { ANOVA } & \text { analysis of variance } \\ \text { CCA } & \text { canonical correspondence analysis } \\ \text { Detrended correspondence analysis } \\ \text { IBI } & \text { Index of Biotic Integrity } \\ \text { PC } & \text { principal components } \\ \text { PCA } & \text { principal component analysis } \\ \text { TWINSPAN } & \text { two-way indicator species analysis }\end{array}$




\title{
Fish Community Structure in Relation to Environmental Variables Within the Sacramento River Basin and Implications for the Greater Central Valley, California
}

\author{
By J ason T. May and Larry R. Brown
}

\section{ABSTRACT}

Twenty-two sites in the Sacramento River Basin, California, were sampled from 1996 to 1998 to characterize fish communities and their relation to water quality and habitat quality. The feasibility of developing an Index of Biotic Integrity (IBI) for the study area was assessed by evaluating six fish community metrics, including percentage of native fish, number of native species, percentage of intolerant fish, number of tolerant species, percentage of omnivorous fish, and percentage of fish with external anomalies. Of the 36 taxa of fish captured during the study, only 13 taxa were native to the drainage. Multivariate analyses identified four site groups that were characterized by four species groups. The distributions of fish species were correlated with elevation of a sampling site and substrate size; however, elevation was correlated with a suite of water-quality and habitat variables. Four of the fish community metrics-percentage of native fish, percentage of intolerant fish, number of tolerant species, and percentage of fish with external anomalies-were responsive to environmental quality. In contrast, number of native species and percentage of omnivorous fish were not correlated with environmental quality. Fish communities in the Sacramento River Basin appeared responsive to environmental gradients, and several of the metrics tested reflected these relations. These results suggest that IBI-type indices can be developed for the basin.

\section{INTRODUCTION}

The rivers of the southwestern United States have been extensively altered, primarily to provide water for agricultural and urban development (Reisner, 1986). In California, the Sacramento River drainage exemplifies many of the problems resulting from such human activities. The Sacramento River Basin (fig. 1) comprises 8 ecological regions, including Central California Valley (hereinafter referred to as the Central Valley), Southern and Central California Chaparral and Woodlands (hereinafter referred to as the Foothills ecoregion), Sierra Nevada, Klamath Mountains, Eastern Cascade Slopes and Foothills, Cascades, Snake River High Desert, and Northern Basin and Range (Omernik, 1987).

Agricultural and urban developments have been most intense in the Central Valley. Water for much of these activities is supplied by large storage reservoirs located in the foothills of the Sierra Nevada. The natural hydrologic flow regime and geomorphic processes of the rivers have been substantially changed by the dams and diversions that provide water supply and flood control for agricultural and municipal purposes (Kahrl and others, 1978; Mount, 1995). Aquatic and terrestrial habitat losses associated with agriculture, mining, urbanization, and water management have reduced or eliminated native communities within the Central Valley. Changes in water and habitat quality in the other, higher elevation, ecological regions have been less significant. Although streams in these regions have been affected by logging, grazing, urbanization, and smaller scale dams and diversions operated for municipal water supply and production of hydroelectricity, development has been less intense (Moyle and 


\section{EXPLANATION}

\section{Ecological Regions}

Central California Valley (Central Valley)

Southern and Central California Chaparral and Woodlands (Foothills)

Sierra Nevada

Klamath Mountains

Eastern Cascades Slopes and Foothills

Cascades

Snake River High Desert

Northern Basin and Range

Sacramento River Basin

Twinspan Site Group

Mountain

Foothill

Large River

Agricultural Drain

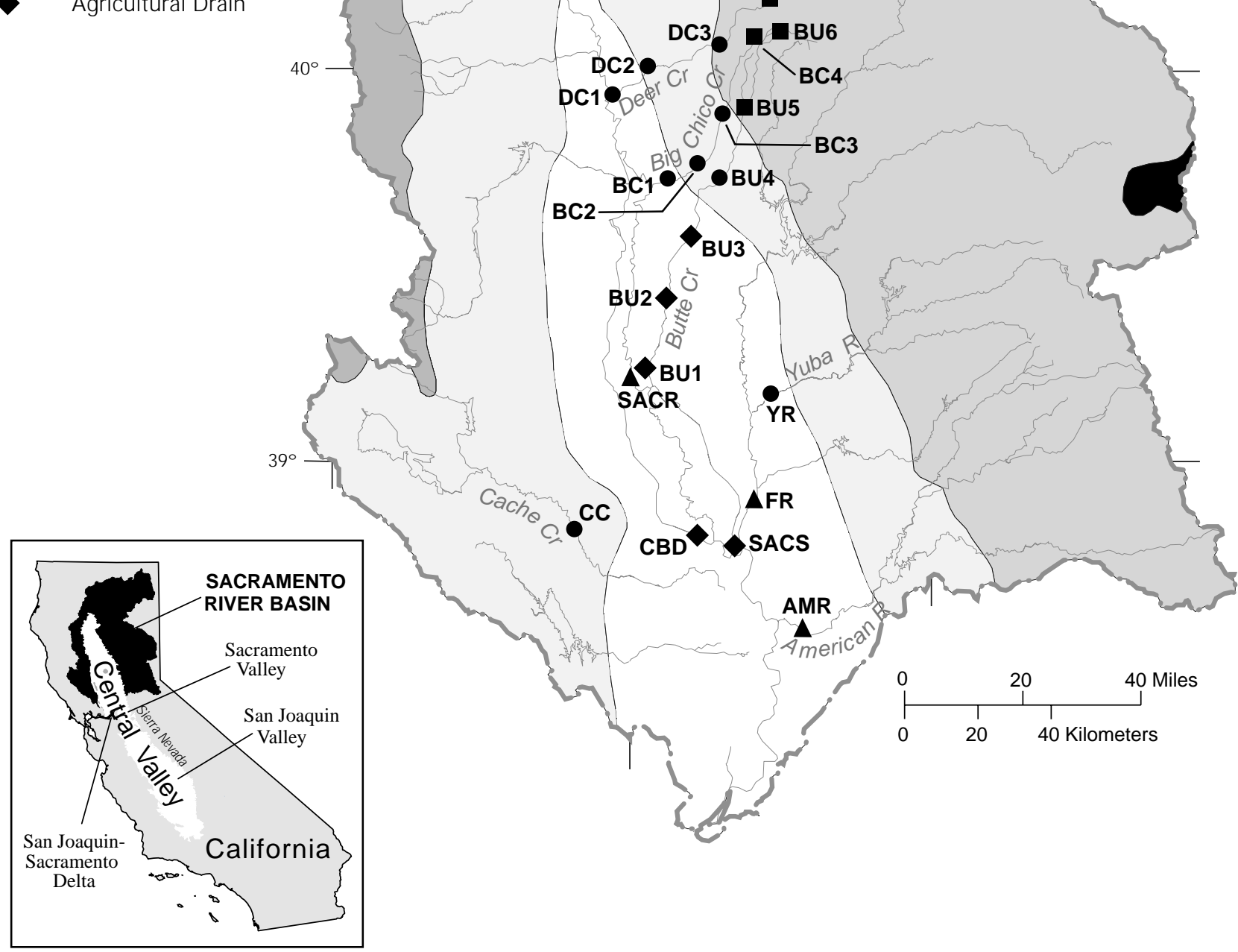

Figure 1. Location of study sites, ecological regions, and TWINSPAN site groups. 
Randall, 1998). Declines and extinctions of native fish species and the introduction of new fish species have occurred in the Central Valley concurrently with these environmental changes (Moyle, 1976a; Brown and Moyle, 1993; Brown, 2000). Results of these previous studies suggest that introduced species adapt better to the altered environments than the native species and may affect native species through both competition and predation.

Although the potential importance of environmental changes and the associated effects on fish community structure have been recognized in the Sacramento River drainage, published studies of fish in the Sacramento River drainage streams have been limited to either species-specific studies (Baltz and others, 1982) or studies of single watersheds (Moyle and others, 1982; Baltz and Moyle, 1993; Gard, 1994). Previous studies of resident fish species in Central Valley streams have concentrated on either valley-floor reaches (Saiki, 1984; Jennings and Saiki, 1990; Brown, 2000) or foothill reaches (Moyle and Nichols, 1973, 1974; Brown and Moyle, 1993). A broader scale assessment of the Sacramento River drainage is needed to assess the importance of environmental changes to fish communities.

Fish community metrics are commonly included in metric-based approaches to assess environmental perturbation of aquatic ecosystems. Brown (2000) suggests that there is a potential for developing a metricbased assessment of environmental perturbation for the study area as has been done for other areas of the country (Fausch and others, 1984; Hughes and Gammon, 1987). The metrics calculated were percentage of native fish, number of native species, percentage of fish intolerant of environmental degradation, number of species tolerant of environmental degradation, percentage of omnivorous species, and percentage of fish with external anomalies, including lesions, tumors, deformities, and parasites.

\section{Purpose and Scope}

The main purpose of this report is to characterize the resident fish communities of selected streams in the Sacramento River Basin from the valley floor to the upper elevation headwaters and to determine their associations with environmental variables. Also, we compare the results of this study with those of a recent study of San Joaquin River drainage fish communities
(Brown, 2000) to provide a perspective on environmental conditions and fish communities in the Central Valley of California, as a whole. Finally, we evaluated six fish community metrics commonly included in metrics-based approaches for the assessment of environmental degradation such as the Index of Biotic Integrity (IBI) developed by Karr (1981).

\section{Acknow ledgments}

This work was done as part of the National Water Quality Assessment Program of the U.S. Geological Survey. Comments by Steve Goodbred and Terry Short (U.S. Geological Survey), Michael Saiki (U.S. Geological Survey, Biological Resources Division, Dixon, California), and Peter Moyle (University of California, Davis) greatly improved this manuscript.

\section{METHODS OF STUDY}

\section{Data Collection}

Twenty-two sites were sampled from 1996 to 1998 (table 1, fig. 1). In 1996, a total of 11 sites were sampled. At 2 of the 11 sites, three adjacent stream reaches were sampled, rather than a single reach, to assess spatial variation within a site. In 1997, 16 sites were sampled, 11 of which were sampled for the first time and 5 of which had also been sampled in 1996. In 1998, 13 sites were sampled, all of which had also been sampled in either 1996 or 1997 . The multiple-year sampling done between 1996 and 1998 was intended to assess annual variability of fish communities. Fish sampling was done during the low-flow period of the year, which typically is late July through late September.

The length of a sampling reach was determined in one of two ways. For reaches with distinct habitat types (pools, riffles, runs), the location and length of the reaches were selected to include two or more repetitions of the habitat types present (Meador and others, 1993a). For all other reaches, reach length was defined as 20 times the wetted channel width-with a minimum and maximum reach length of 150 to $300 \mathrm{~m}$ for wadeable streams, and 500 to $1,000 \mathrm{~m}$ for larger, non-wadeable streams. 
Fish were sampled by an appropriate combination of electrofishing (boat or backpack), seining (3-, 9-, or 15-m length with 6-mm mesh), or snorkeling, as determined by the environmental conditions at each site (Meador and others, 1993b). At sites where federally protected and state-protected anadromous salmonids were expected, snorkeling was the primary method used to quantify community structure. Sampling methods were consistent among years at 12 sites. At six sites (BC2, BC4, BU4, BU6, SACR, and YR), different sampling methods were used in 1998 because of endangered-species restrictions, equipment availability, or site conditions.

Captured fish were identified and counted. All fish were examined for external anomalies. Fish observed during snorkeling surveys were identified and counted. Assessment of physiochemical parameters was usually done on the same day or within several days of fish collections. Water samples for measurements of specific conductance, $\mathrm{pH}$, alkalinity, nutrients, and major ions were collected using widthand depth-integrated sampling or by grab sampling. Nutrient and major-ion samples were collected at selected sites. Field measurements of specific conductance, $\mathrm{pH}$, water temperature, and dissolved oxygen were made with electronic meters. Alkalinity was determined by titration. Nutrient and major-ions samples were analyzed using standard methods (Fishman and Friedman, 1989). Instantaneous discharge was determined at ungaged sites.

Habitat variables were measured at six transects within each sampling reach (Meador and others, 1993a). At sites with repeating habitat types, transects were placed to reflect the relative availability of each habitat type; for the other sites, the transects were placed at equally spaced intervals. Reach length and wetted channel width were measured with a graduated tape or an electronic rangefinder. The extent of riparian canopy closure was measured from midstream at each transect with a clinometer as the number of degrees of

Table 1. Site name, site code, and year(s) sampled for study sites in the Sacramento River Basin, California

[Location of sites shown in figure 1. Land-use categories: UD, undeveloped land; AG, agricultural land use; UR, urban land use]

\begin{tabular}{|c|c|c|c|c|}
\hline Site name & Site code & $\begin{array}{l}\text { Elevation } \\
\text { (meters) }\end{array}$ & Land use & $\begin{array}{c}\text { Year(s) } \\
\text { sampled }\end{array}$ \\
\hline McCloud River at the Nature Conservancy Preserve $^{\top}$ & $\mathrm{MC}$ & 682.8 & UD & $1996-98$ \\
\hline Deer Creek below Hwy 99 Bridge & DC1 & 60.9 & UD & 1997-98 \\
\hline Deer Creek near Vina $^{1}$ & DC2 & 146 & UD & 1996-98 \\
\hline Deer Creek near Ishi Wilderness Area & DC3 & 524.3 & UD & 1997 \\
\hline Deer Creek at Potato Patch Campground & DC4 & $1,048.5$ & UD & 1997-98 \\
\hline Big Chico Creek at Chico & $\mathrm{BC} 1$ & 50.3 & UR & 1996-98 \\
\hline Big Chico Creek above Chico & $\mathrm{BC} 2$ & 82.3 & UD & 1996-98 \\
\hline Big Chico Creek near Forest Ranch & $\mathrm{BC} 3$ & 316.5 & UD & 1997 \\
\hline Big Chico Creek at Soda Springs Campground & $\mathrm{BC} 4$ & $1,133.9$ & UD & 1997-98 \\
\hline Butte Creek near Meridian & BU1 & 15.2 & AG & 1997 \\
\hline Butte Creek near Afton & BU2 & 21.3 & AG & 1997 \\
\hline Butte Creek near Nelson & BU3 & 36.6 & AG & 1997 \\
\hline Butte Creek near Paradise & BU4 & 103.6 & UD & 1997-98 \\
\hline Butte Creek near Butte Meadows & BU5 & 585.2 & UD & 1997 \\
\hline Butte Creek at Cherry Hill Campground & BU6 & $1,426.5$ & UD & 1997-98 \\
\hline Sacramento River near Colusa & SACR & 12.2 & UD & 1996, 1998 \\
\hline Cache Creek near Guinda & $\mathrm{CC}$ & 106.7 & UD & $1996-97$ \\
\hline Yuba River near Marysville & YR & 22.4 & UD & 1996,1998 \\
\hline Feather River near Nicholas & FR & 6.1 & UD & 1996, 1998 \\
\hline Colusa Basin Drain near Knights Landing & CBD & 7.6 & AG & 1996,1998 \\
\hline Sacramento Slough near Karnak & SACS & 6.1 & AG & 1996 \\
\hline American River at Sacramento & AMR & 9.1 & UD & 1996 \\
\hline
\end{tabular}

${ }^{1}$ Sites that were sampled for spatial variability of fish-community structure. 
open sky above the transect. Depth, velocity, and substrate were measured at three or more points within each transect. Measurement points generally were at about one-quarter, one-half, and three-quarters of the stream width. Depth was measured with a wading rod. Velocity was measured with an electronic flow meter (Marsh-McBirney). Substrate was estimated as the dominant substrate at each transect point. Habitat data were examined for normality prior to analysis and log transformed when appropriate. Variables with multiple measurements at a site were analyzed as mean or geometric-mean values.

Stream gradient, stream sinuosity, and elevation were determined from U.S. Geological Survey 1:24,000 topographic maps. Stream sinuosity was measured as river distance divided by the straight-line distance between the upstream and downstream ends of a segment of stream (minimum of $2 \mathrm{~km}$ ). Basin areas and percentages of agricultural and urban land use within each area were determined using geographic information system databases (U.S. Geological Survey, 1986).

\section{Data Analysis}

Multivariate analyses were used to explore fish assemblage structure and the relation of assemblage structure to environmental characteristics. Fish were analyzed as percentage abundance at each site. To minimize the effect of rare species in analyses, only species that were found at three or more sites and constituted at least 5 percent of the fish captured at one site were included in the analyses (Gauch, 1982). However, Western mosquitofish (Gambusia affinis) and lampreys (Lampetra sp.) were not included in multivariate analyses owing to poor capture efficiency; the 6.4-mm (0.25-in.) mesh size of nets used in this study allowed most mosquitofish and lamprey larvae to easily escape.

Species and site groups were defined using two multivariate methods: two-way indicator species analysis (TWINSPAN) (Hill, 1979), and canonical correspondence analysis (CCA) using the statistical package CANOCO (ter Braak, 1986, 1987; Jongman and others, 1987). Data from only one sample (1996 or 1997) were used for these analyses in order to eliminate possible bias owing to multiple samples from a site.

TWINSPAN is a divisive numerical classification technique developed for hierarchical classification of community data. The analysis was limited to three divisions (level-1, level-2, and level-3) potentially yielding eight groups. Level-3 groups were used for more detailed examination of site and species groups. CCA is a direct gradient ordination technique for relating species and sites to physiochemical parameters. Sites and species groups were defined by visual examination of ordination plots and were then compared with TWINSPAN groupings.

The four groups defined by the TWINSPAN level-2 division were used for comparisons of environmental and fish community metric data among site groups using analysis of variance (ANOVA) because several level-3 division groups included only one or two sites. When the ANOVA was significant, pairwise comparisons were done to assess differences between the TWINSPAN site groups.

Principal component analysis (PCA) was used to define subsets of water-quality and habitat variables. PCA was limited to the 14 of the 22 sampling sites at which nutrients and major-ion data were collected. The main purpose of this analysis was to determine whether the variables measured at all 22 sites accurately characterized the gradients in nutrients and major ions within the basin. PCA was done for 32 environmental variables representing various spatial scales; the variables range from watershed characteristics to instream habitat and water chemistry. Variables were examined for normality and were $\log _{10}(x+1)$ transformed where appropriate and then standardized to a mean of 0 and standard deviation of 1 . Only principal components (PC) with eigenvalues greater than 1 were retained for interpretation. Loadings were qualitatively designated as "high" for absolute values greater than 0.60 .

Associations of species and sites with environmental variables were investigated using CCA data from all 22 sites. CCA was done in the forward selection mode, and the significance of each variable was tested in a sequential fashion using a Monte-Carlo simulation algorithm before it was added to the final model. All variables significant at $p<0.05$ were included in the final model.

Spatial and annual variations of fish communities were evaluated using detrended correspondence analysis (DCA). DCA was done using CANOCO (ter Braak, 1987). Data for all years and reaches were included. Only species that were found at three or more sites and that made up at least 5 percent of the fish captured at one site were included in the DCA. Detrended correspondence analysis is an improved eigenvector 


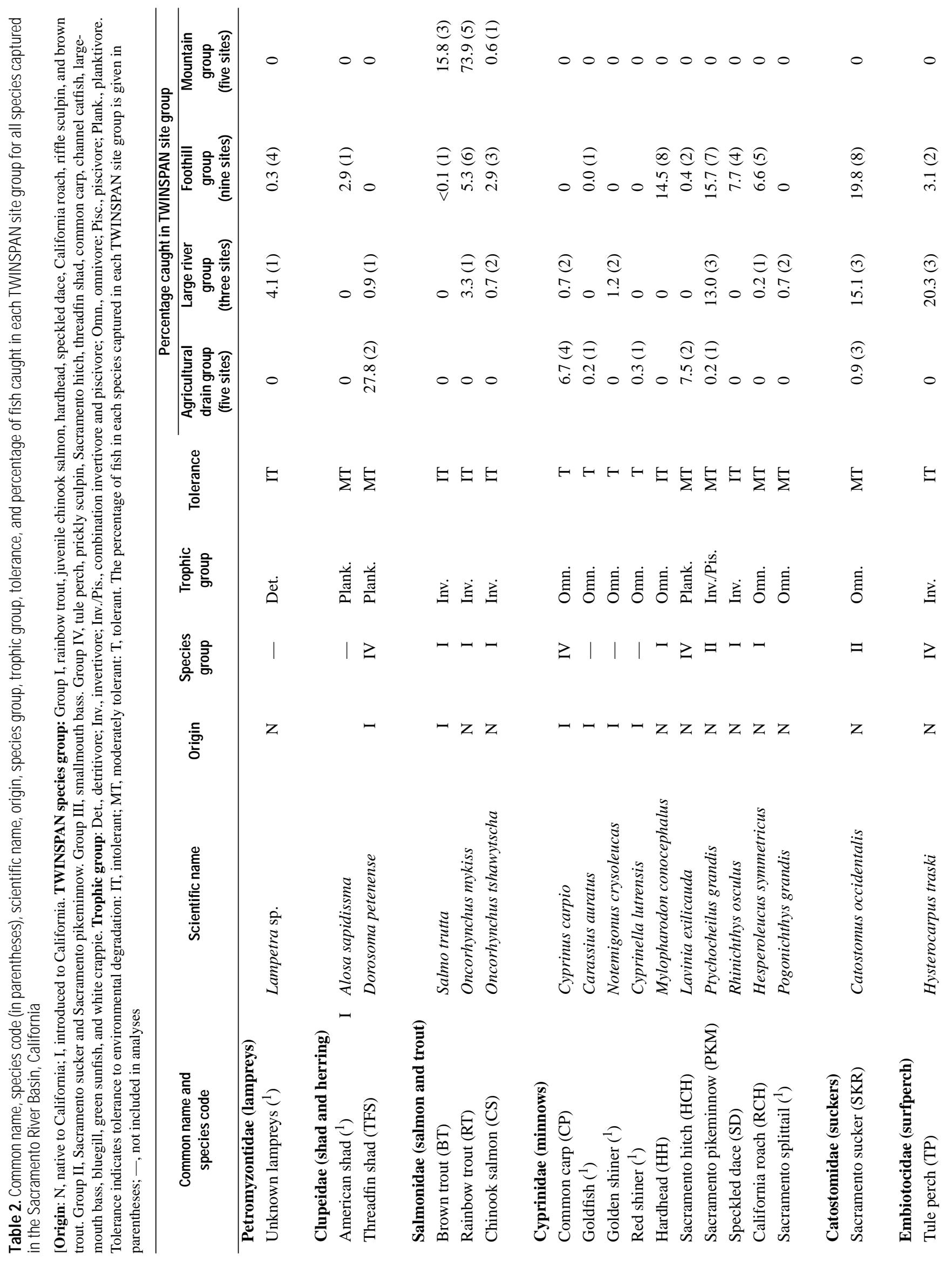




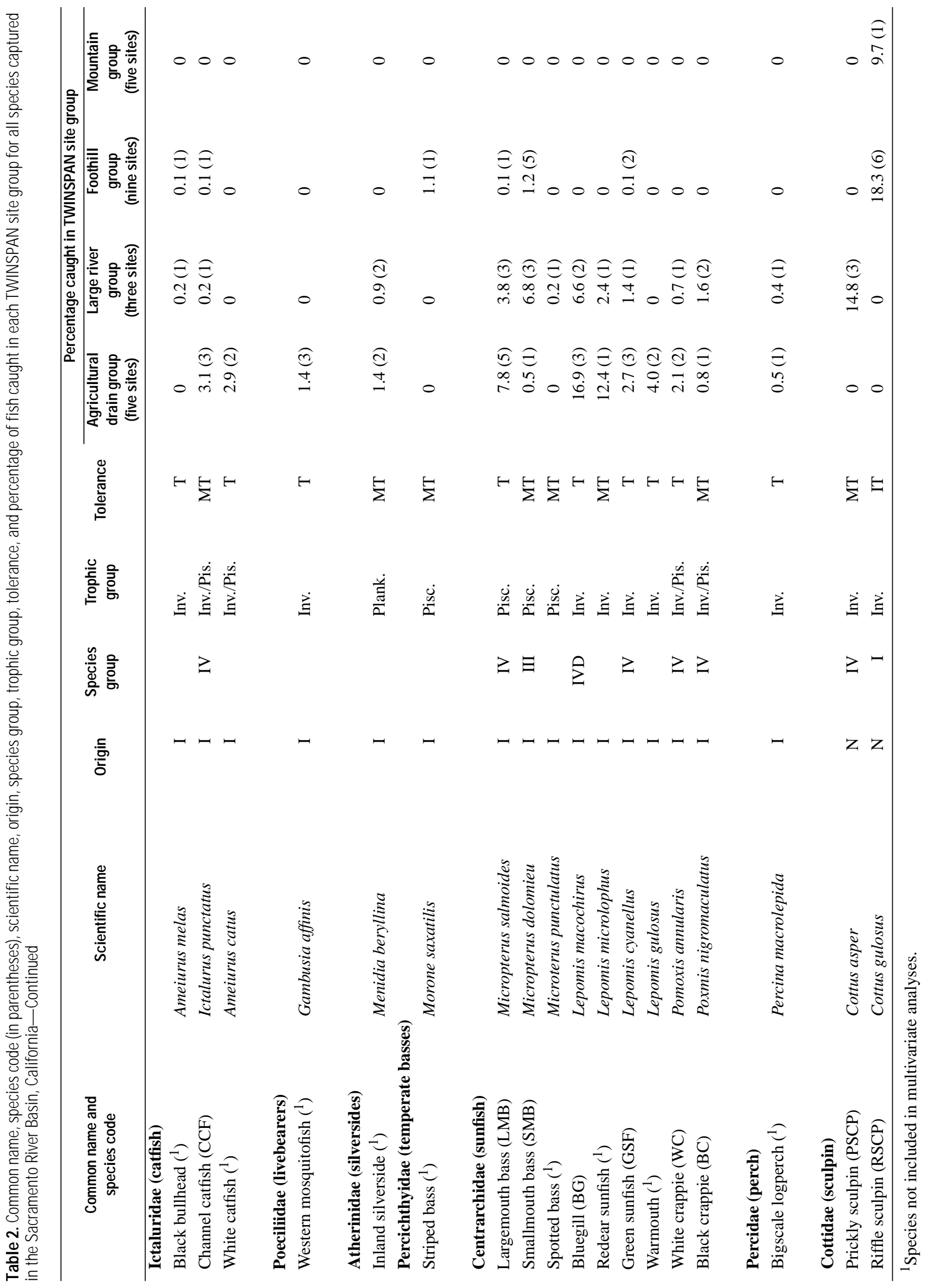


ordination technique based on reciprocal averaging; DCA corrects the two main faults of this technique-arch distortion and violation of the orthogonality criterion (Gauch, 1982). Reciprocal averaging or correspondence analysis is a multivariate technique that maximizes the correlation between species scores and sample scores along an assumed gradient (Hill and Gauch, 1980).

Calculation of metric values was based on all individual species captured. Native species were determined from descriptions by Moyle (1976b). Trophic and tolerance categories were derived from work by Moyle (1976b), Moyle and Nichols (1973, 1974) and P.B. Moyle (University of California, Davis, written commun., 1996).

Multivariate analyses were done using both percentage abundance and presence-absence data. The two analyses resulted in only minor differences in results. Only the percentage-abundance results are presented.

\section{FISH COM MUNITY STRUCTURE}

A total of 36 fish taxa were captured during the study. Thirteen taxa were native to California and 23 taxa were introduced (table 2). Only 21 of the total 36 fish taxa were used for multivariate analyses. Of these 21 , only 13 taxa are native to California.

TWINSPAN species groups: The initial TWINSPAN division generally separated native species from introduced species, with the exception that brown trout and smallmouth bass were included with the native species, and tule perch, prickly sculpin, and Sacramento hitch were included with the introduced species. The second level of division resulted in four groups of species:

I: The first of the four species groups defined by the second TWINSPAN division consisted almost entirely of native species, except for brown trout, an introduced species. The native species included rainbow trout, juvenile chinook salmon, hardhead, speckled dace, California roach, and riffle sculpin. The level3 division of this group separated the two trout species from the other species because they had high percentage abundances at the highest elevation sites. The other species in the first species group, juvenile chinook salmon, hardhead, California roach, speckled dace, and riffle sculpin, are characteristic of the Foothill ecoregion.
II. Sacramento sucker and Sacramento pikeminnow composed the second TWINSPAN species group. Both of these species had wide distributions over most of the Sacramento River Basin. Sacramento sucker was captured at 14 of 22 sites, and Sacramento pikeminnow was found at 11 of 22 sites. Sacramento suckers were found in 3 of the 4 stream types sampled; the highest elevation sites were dominated by trout.

III. The third species group consisted of a single taxon, smallmouth bass; this species was found at 9 of the 22 sampling sites. The distribution of smallmouth bass included large river sites and sites on parts of the tributary streams on the lower valley floor.

IV. The fourth species group was composed primarily of introduced species but included three native species: tule perch, prickly sculpin, and Sacramento hitch. The introduced species (threadfin shad, common carp, channel catfish, largemouth bass, bluegill, green sunfish, and white crappie) (table 2) in this species group were commonly found at the large river sites and agricultural drainage sites. Tule perch and prickly sculpin were predominantly found at the large river sites.

TWINSPAN site groups: The first TWINSPAN division of sites roughly separated the large river and agricultural drainage sites on the valley floor of the Central Valley ecological region from the sites located in the Foothills and Sierra Nevada ecological regions. The second TWINSPAN division resulted in the following four site groups (fig. 1).

1. The mountain (MT) site group consisted of five high-elevation tributary sites in which the fish community was dominated by brown trout, rainbow trout, and juvenile chinook salmon (table 2). The level3 division of this group separated three sites (BC4, BU6, and MC) from the other two sites (BU4 and DC4) on the basis of the high percentage abundances of brown trout.

2. The foothill (FH) site group consisted of nine sites within the Foothills and Central Valley ecoregions. These sites were dominated by native minnow and sucker species, including Sacramento pikeminnow, hardhead, speckled dace, California roach, and Sacramento sucker (table 2). The level-3 division of this group separated sites in the mid-elevation foothills (DC2, DC3, BC3, and BU4) from those on the valley floor (DC1, BC1, and YR). 
3. The large river (LR) site group included three large river sites that had similar percentage abundances of the native tule perch and prickly sculpin, as well as the introduced black crappie. Tule perch was found at other site types, although at relatively low abundances. The other species captured at large river sites were a mixture of native species characteristic of the foothill group and the introduced species found in the fourth group, the agricultural drain group (table 2).
4. The agricultural drain (AG) site group included five sites in areas in which agricultural land use was predominant. These sites were dominated by introduced species, including threadfin shad, common carp, largemouth bass, and bluegill (table 2). The native species-Sacramento hitch, Sacramento pikeminnow, and Sacramento sucker-were found in low numbers (table 2). The level-3 division of this group separated out two sites in the lower Butte Creek watershed (BU2 and BU3) that had relatively low abundances of fish.

Table 3. Principal component loadings for habitat and water-quality variables from principal component analysis of physical data from 14 of the 22 sites sampled in the Sacramento River Basin, California

[Values greater than 0.60 (in bold) were considered high. $\mathrm{mg} / \mathrm{L}$, milligram per liter; $\mu \mathrm{S} / \mathrm{cm}$, microsiemens per centimeter at $25^{\circ} \mathrm{C} ;{ }^{\circ} \mathrm{C}$, degree $\mathrm{Celsius;} \mathrm{m}$, meter; $\mathrm{km}^{2}$, square kilometer; $\mathrm{m}^{3} / \mathrm{s}$, cubic meter per second; $\mathrm{m} / \mathrm{s}$, meter per second]

\begin{tabular}{|c|c|c|c|c|c|}
\hline \multirow{2}{*}{ Variable } & \multicolumn{5}{|c|}{ Principal component } \\
\hline & 1 & 2 & 3 & 4 & 5 \\
\hline Agricultural land (percent) ${ }^{1,2}$ & 0.95 & $\left({ }^{3}\right)$ & $\left({ }^{3}\right)$ & $\left({ }^{3}\right)$ & $\left({ }^{3}\right)$ \\
\hline Nitrate + nitrite $(\mathrm{mg} / \mathrm{L})^{2}$ & .94 & $\left({ }^{3}\right)$ & $\left({ }^{3}\right)$ & $\left({ }^{3}\right)$ & $\left({ }^{3}\right)$ \\
\hline Sulfate $(\mathrm{mg} / \mathrm{L})^{2}$ & .91 & $\left({ }^{3}\right)$ & $\left({ }^{3}\right)$ & $\left({ }^{3}\right)$ & $\left({ }^{3}\right)$ \\
\hline Calcium (mg/L) & .89 & 0.37 & $\left({ }^{3}\right)$ & $\left({ }^{3}\right)$ & $\left({ }^{3}\right)$ \\
\hline Magnesium (mg/L) & .89 & .39 & $\left({ }^{3}\right)$ & $\left({ }^{3}\right)$ & $\left({ }^{3}\right)$ \\
\hline Dissolved phosphorus (mg/L) & .88 & $\left({ }^{3}\right)$ & $\left({ }^{3}\right)$ & $\left({ }^{3}\right)$ & $\left({ }^{3}\right)$ \\
\hline Agricultural and urban land (percent) ${ }^{1,2}$ & .88 & $\left({ }^{3}\right)$ & $\left({ }^{3}\right)$ & $\left({ }^{3}\right)$ & $\left({ }^{3}\right)$ \\
\hline Chloride $(\mathrm{mg} / \mathrm{L})$ & .84 & .31 & $\left({ }^{3}\right)$ & $\left({ }^{3}\right)$ & $\left({ }^{3}\right)$ \\
\hline Ortho-phosphate (mg/L) & .81 & $\left({ }^{3}\right)$ & 0.35 & $\left({ }^{3}\right)$ & $\left({ }^{3}\right)$ \\
\hline Sodium $(\mathrm{mg} / \mathrm{L})$ & .81 & .33 & $\left({ }^{3}\right)$ & $\left({ }^{3}\right)$ & $\left({ }^{3}\right)$ \\
\hline Fluoride (mg/L) & .80 & $\left({ }^{3}\right)$ & $\left({ }^{3}\right)$ & $\left({ }^{3}\right)$ & $\left({ }^{3}\right)$ \\
\hline Specific conductance $(\mu \mathrm{S} / \mathrm{cm})^{1,2}$ & .78 & .52 & $\left({ }^{3}\right)$ & $\left({ }^{3}\right)$ & $\left({ }^{3}\right)$ \\
\hline Total phosphorus (mg/L) & .73 & $\left({ }^{3}\right)$ & -.44 & $\left({ }^{3}\right)$ & $\left({ }^{3}\right)$ \\
\hline Water temperature $\left({ }^{\circ} \mathrm{C}\right)$ & .73 & $\left({ }^{3}\right)$ & $\left({ }^{3}\right)$ & $\left({ }^{3}\right)$ & $\left({ }^{3}\right)$ \\
\hline Akalinity $(\mathrm{mg} / \mathrm{L})^{1,2}$ & .73 & .56 & $\left({ }^{3}\right)$ & $\left({ }^{3}\right)$ & $\left({ }^{3}\right)$ \\
\hline Mean dominant substrate ${ }^{1}$ & -.84 & $\left({ }^{3}\right)$ & $\left({ }^{3}\right)$ & $\left({ }^{3}\right)$ & $\left({ }^{3}\right)$ \\
\hline Elevation $(\mathrm{m})^{1,2}$ & -.65 & .53 & .41 & $\left({ }^{3}\right)$ & $\left({ }^{3}\right)$ \\
\hline Mean depth (m) ${ }^{1}$ & .58 & -.52 & $\left({ }^{3}\right)$ & $\left({ }^{3}\right)$ & $\left({ }^{3}\right)$ \\
\hline Ammonia (mg/L) & .57 & $\left({ }^{3}\right)$ & .55 & $\left({ }^{3}\right)$ & \\
\hline Basin area $\left(\mathrm{km}^{2}\right)^{1,2}$ & .49 & -.83 & $\left({ }^{3}\right)$ & $\left({ }^{3}\right)$ & $\left({ }^{3}\right)$ \\
\hline Discharge $\left(\mathrm{m}^{3} / \mathrm{s}\right)^{1,2}$ & .38 & -.73 & $\left({ }^{3}\right)$ & $\left({ }^{3}\right)$ & $\left({ }^{3}\right)$ \\
\hline $\mathrm{pH}^{1}$ & $\left({ }^{3}\right)$ & .86 & $\left({ }^{3}\right)$ & $\left({ }^{3}\right)$ & $\left({ }^{3}\right)$ \\
\hline Dissolved oxygen $(\mathrm{mg} / \mathrm{L})^{1}$ & -.49 & $\left({ }^{3}\right)$ & .45 & .49 & $\left({ }^{3}\right)$ \\
\hline Potassium (mg/L) & $\left({ }^{3}\right)$ & .57 & $\left({ }^{3}\right)$ & -.59 & 0.41 \\
\hline Silica (mg/L) & $\left({ }^{3}\right)$ & .78 & $\left({ }^{3}\right)$ & $\left({ }^{3}\right)$ & $\left({ }^{3}\right)$ \\
\hline Mean velocity $(\mathrm{m} / \mathrm{s})$ & $\left({ }^{3}\right)$ & -.56 & .52 & $\left({ }^{3}\right)$ & $\left({ }^{3}\right)$ \\
\hline Mean width $(m)^{1,2}$ & .40 & -.81 & $\left({ }^{3}\right)$ & $\left({ }^{3}\right)$ & $\left({ }^{3}\right)$ \\
\hline Open canopy (degrees) ${ }^{1}$ & .44 & -.73 & $\left({ }^{3}\right)$ & -.43 & $\left({ }^{3}\right)$ \\
\hline Canopy cover (percent) ${ }^{1}$ & -.32 & .60 & $\left({ }^{3}\right)$ & .48 & $\left({ }^{3}\right)$ \\
\hline Stream gradient (percent) ${ }^{1}$ & -.57 & .38 & $\left({ }^{3}\right)$ & $\left({ }^{3}\right)$ & .38 \\
\hline Stream sinuosity ${ }^{1,2}$ & $\left({ }^{3}\right)$ & -.48 & $\left({ }^{3}\right)$ & $\left({ }^{3}\right)$ & .56 \\
\hline Proportion of variance explained & .44 & .22 & .07 & .06 & .05 \\
\hline
\end{tabular}

${ }^{1}$ Included in canonical correspondence analyses.

${ }^{2}$ Variables were log transformed for analyses.

${ }^{3}$ Loading was less than 0.30 . 


\section{RELATION TO ENVIRONMENTAL VARIAB LES}

\section{Principle Component Analysis}

Principal component analysis yielded seven principal components with eigenvalues greater than 1 , which explained 93 percent of the variance in the data. Variable loadings for the first five PCs are given in table 3. The first two PCs accounted for 44 and 22 percent of the variance, respectively (fig. 2).

For all major-ion and nutrient variables for PC 1 , loadings were high, except for potassium and silica (table 3). Loads for other variables that were high included elevation, mean dominant substrate size, specific conductance, water temperature, alkalinity, and agricultural and urban land use. The results of PC 1 indicate that patterns of variation in concentrations of major ions and nutrients among sites are largely represented by patterns of variation in more general variables. Results of PC 1 indicates a gradient from the high-elevation Sierra Nevada sites to the lower elevation valley-floor sites; the results also emphasize the variables that distinguish the agricultural drain sites (CBD and SACS) from the other sites.

PC 2 separates sites on the basis of discharge, basin area, mean channel width, and open canopy. The high-elevation sites (DC4 and MC) generally were narrow and their basin areas were small. The lower elevation sites were more variable in width and basin area

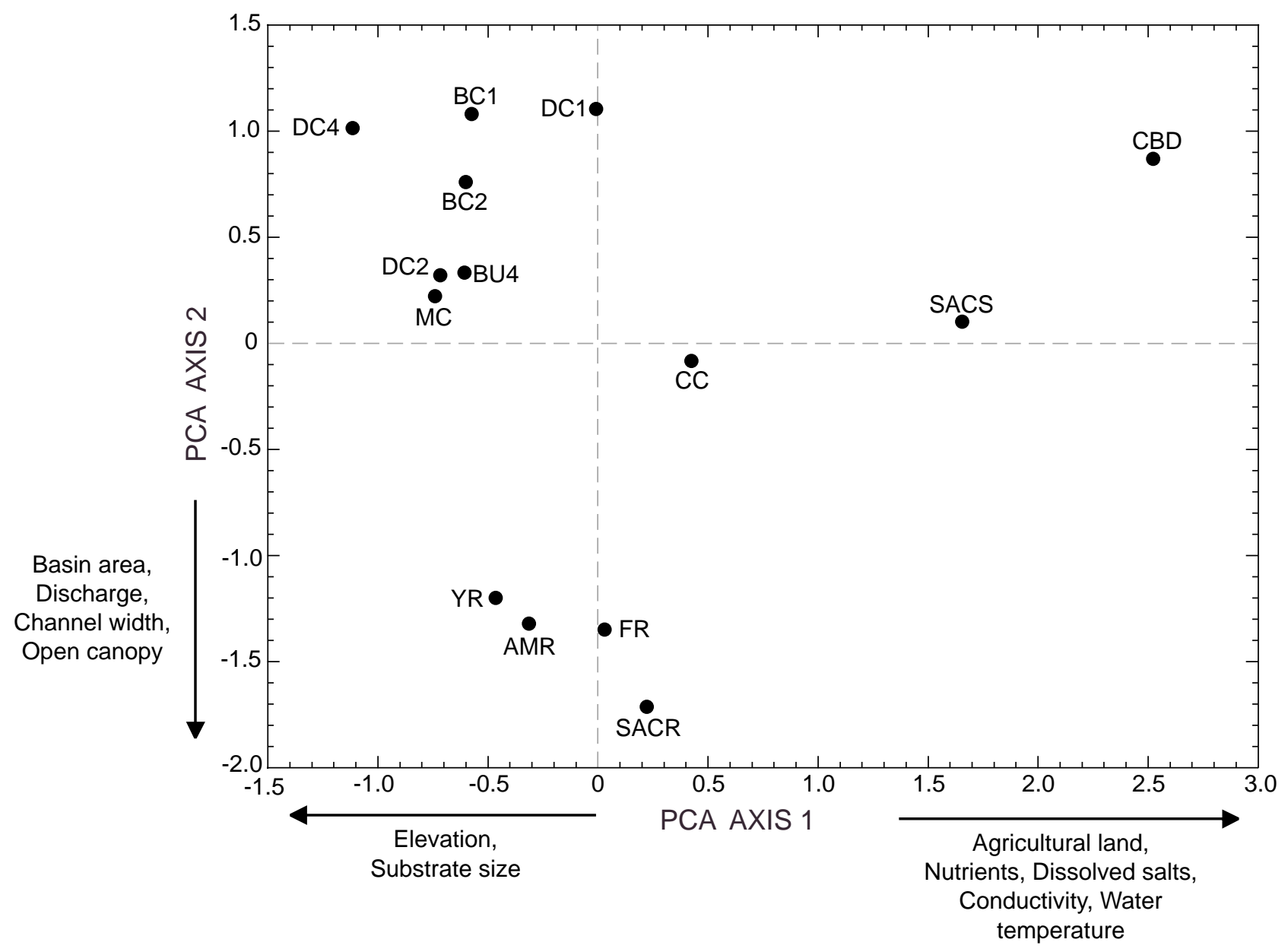

Figure 2. Principal component analysis (PCA) plot of site scores on the first two principal components derived from the environmental variables for sampling sites in the Sacramento River Basin, California. 
because of the inclusion of small tributary streams (BC1, BC2, DC1, DC2, BU4, and CC), sloughs, and drains (CBD and SACS) with large tributary streams (AMR, FR, and YR) and the Sacramento River (SACR). No variables were loaded high on any of the remaining PCs.
The four TWINSPAN site groups had distinctly different physical characteristics (table 4). Fifteen of 18 ANOVA comparisons were statistically significant. The pairwise comparisons were somewhat complex but generally were consistent with the gradient described by PC 1.

Table 4. M ean and range of selected water-quality and habitat variables for the four site groups resulting from TW INSPAN analysis of fish species percentage abundance in the Sacramento River Basin, California

[Mean, geometric mean for log-transformed variables. Range of variable given in parentheses. See figure 3 for location of group sites. TWINSPAN, twoway indicator species analysis. Values with different letters $\left({ }^{\mathrm{A}-\mathrm{C}}\right)$ indicate significant difference among site groups, and values with the same letter indicate that the difference was not significant. $\mu \mathrm{S} / \mathrm{cm}$, microsiemens per centimeter at $25^{\circ} \mathrm{C}$; ${ }^{\circ} \mathrm{C}$, degree Celsius; mg/L, milligram per liter; $\mathrm{m}^{3} / \mathrm{s}$, cubic meter per second; $\mathrm{m}$, meter; $\mathrm{m} / \mathrm{s}$, meter per second; $\mathrm{km}^{2}$, square kilometer; $\mathrm{mm}$, millimeter]

\begin{tabular}{|c|c|c|c|c|}
\hline \multirow[b]{2}{*}{ Variable } & \multicolumn{4}{|c|}{ TWINSPAN site group } \\
\hline & $\begin{array}{l}\text { Agricultural } \\
\text { drain group } \\
\text { (five sites) }\end{array}$ & $\begin{array}{l}\text { Large river } \\
\text { group } \\
\text { (three sites) }\end{array}$ & $\begin{array}{c}\text { Foothill } \\
\text { group } \\
\text { (nine sites) }\end{array}$ & $\begin{array}{l}\text { Mountain } \\
\text { group } \\
\text { (five sites) }\end{array}$ \\
\hline \multicolumn{5}{|l|}{ Water-quality variable } \\
\hline $\mathrm{pH}$ & $8^{\mathrm{A}, \mathrm{B}}(7.4-8.4)$ & $6.9^{\mathrm{A}}(6.7-7.2)$ & $7.9^{\mathrm{B}}(6.3-8.4)$ & $8.1^{\mathrm{B}}(7.9-8.3)$ \\
\hline Specific conductance $(\mu \mathrm{S} / \mathrm{cm})^{1}$ & $370^{\mathrm{A}}(246-741)$ & $78^{\mathrm{B}}(43-121)$ & $144^{\mathrm{B}}(72-311)$ & $119^{\mathrm{B}}(95-162)$ \\
\hline Dissolved oxygen $(\mathrm{mg} / \mathrm{L})$ & $7.9(6.2-9.6)$ & $9.2(8.4-10)$ & $8.8(7.8-10)$ & $9.9(7.6-11.2)$ \\
\hline Alkalinity $(\mathrm{mg} / \mathrm{L})$ & $162^{\mathrm{A}}(125-237)$ & $32^{\mathrm{C}}(17-53)$ & $68^{\mathrm{B}}(33-125)$ & $60^{\mathrm{B}, \mathrm{C}}(43-87)$ \\
\hline \multicolumn{5}{|l|}{ Habitat variables } \\
\hline Discharge $\left(\mathrm{m}^{3} / \mathrm{s}\right)^{1}$ & $9.8^{\mathrm{A}, \mathrm{B}}(1.5-26.7)$ & $64^{\mathrm{A}}(29.6-146.9)$ & $3.2^{\mathrm{B}}(1.1-14.7)$ & $3.3^{\mathrm{B}}(1.6-5.7)$ \\
\hline Water temperature $\left({ }^{\circ} \mathrm{C}\right)$ & $26.5^{\mathrm{A}}(24.6-29.0)$ & $17.8^{\mathrm{B}, \mathrm{C}}(16.8-19.4)$ & $19.7^{\mathrm{B}}(14.4-30.7)$ & $12^{\mathrm{C}}(7.2-20.1)$ \\
\hline Mean depth (m) & $1.6^{\mathrm{A}, \mathrm{B}}(0.45-2.76)$ & $2.5^{\mathrm{A}}(1.11-4.58)$ & $0.89^{\mathrm{B}}(0.30-1.23)$ & $0.91^{\mathrm{A}, \mathrm{B}}(0.55-1.19)$ \\
\hline Mean velocity $(\mathrm{m} / \mathrm{s})$ & $0.16(0-0.24)$ & $0.49(0.11-0.92)$ & $0.38(0.08-0.91)$ & $0.25(0.10-0.47)$ \\
\hline Mean dominant substrate ${ }^{2}$ & $1.6^{\mathrm{A}}(1-2)$ & $3.5^{\mathrm{B}}(3-4.4)$ & $5.0^{\mathrm{C}}(4-5.8)$ & $5.3^{\mathrm{C}}(5-5.5)$ \\
\hline Mean width $(\mathrm{m})^{1}$ & $33.0^{\mathrm{A}, \mathrm{B}, \mathrm{C}}(14.5-48.4)$ & $79.4^{\mathrm{C}}(52.5-123.3)$ & $18.9^{\mathrm{A}, \mathrm{B}}(6.4-44.3)$ & $15.2^{\mathrm{B}}(8.5-29.0)$ \\
\hline Open canopy angle (degrees) & $124^{\mathrm{A}, \mathrm{B}}(105-155)$ & $174^{\mathrm{A}}(162-180)$ & $100^{\mathrm{B}}(26-171)$ & $40^{\mathrm{C}}(20-67)$ \\
\hline Canopy cover (percent) & $20^{\mathrm{A}, \mathrm{B}}(4-32)$ & $1^{\mathrm{A}}(0-3)$ & $25^{\mathrm{A}, \mathrm{B}}(0-87)$ & $46^{\mathrm{B}}(23-72)$ \\
\hline Stream gradient (percent) & $0.05^{\mathrm{A}}(0-0.13)$ & $0.05^{\mathrm{A}}(0.02-0.09)$ & $0.71^{\mathrm{A}}(0.17-2.53)$ & $2.95^{\mathrm{A}, \mathrm{B}}(1.51-5.19)$ \\
\hline Stream sinuosity ${ }^{1}$ & $2.17(2.0-2.4)$ & $2.4(2.1-2.9)$ & $2.2(2.1-2.3)$ & $2.1(2.0-2.2)$ \\
\hline Elevation $(\mathrm{m})^{1}$ & $15^{\mathrm{A}}(7-38)$ & $10^{\mathrm{A}}(7-13)$ & $106^{\mathrm{B}}(23.3-525)$ & $927^{\mathrm{C}}(586-1,429)$ \\
\hline Agricultural land (percent) ${ }^{1}$ & $30^{\mathrm{A}}(3-65)$ & $6^{\mathrm{A}, \mathrm{B}}(4-8)$ & $2^{\mathrm{B}, \mathrm{C}}(0-9)$ & $1^{\mathrm{C}}(0-1.3)$ \\
\hline Agricultural and urban land (percent) ${ }^{1}$ & $38^{\mathrm{A}}(8-68)$ & $8^{\mathrm{A}, \mathrm{B}}(7-9)$ & $2^{\mathrm{B}, \mathrm{C}}(0-11)$ & $1^{\mathrm{C}}(0-1.7)$ \\
\hline Basin area $\left(\mathrm{km}^{2}\right)^{1}$ & $1,758^{\mathrm{A}, \mathrm{B}}(407-4,256)$ & $13,459^{\mathrm{A}}(5,046-31,695)$ & $519^{\mathrm{B}, \mathrm{C}}(152-3,475)$ & $179^{\mathrm{C}}(39-1,130)$ \\
\hline
\end{tabular}

${ }^{1}$ These variables were $\log _{10}(\times+1)$ transformed for analyses.

${ }^{2}$ Dominant substrate was classified as organic detritus, silt, mud, sand (0.02-2 mm), gravel (2-64 mm), cobble (64-256 mm), boulder (greater than $256 \mathrm{~mm}$ ), or bedrock or hardpan (solid rock or clay forming a continuous surface).

Table 5. Results of canonical correspondence analysis relating fish percentage abundance data to environmental variables in the Sacramento River Basin, California

[Canonical coefficients in bold have T-values greater than 2.1, indicating that the variable makes an important contribution to the canonical axis (ter Braak, 1987)]

\begin{tabular}{lccc}
\hline \multicolumn{1}{c}{ Environmental variable } & Eigenvalue & \multicolumn{2}{c}{ Canonical coefficient } \\
\cline { 2 - 4 } & & Axis 1 & $\mathbf{A x i s ~ 2 ~}$ \\
\hline Mean dominant substrate & 0.82 & $\mathbf{- 0 . 5 7}$ & $\mathbf{- 1 . 3 1}$ \\
Elevation & 0.55 & $\mathbf{- 0 . 4 9}$ & $\mathbf{1 . 3 4}$ \\
Cumulative percentage of species variance explained & & 16.5 & 26.3 \\
Cumulative percentage of species-environment relation explained & & 62.9 & 100.0 \\
\hline
\end{tabular}




\section{Canonical Correspondence Analysis}

The forward selection procedure of CCA resulted in the retention of 2 of 18 environmental variables (table 5). Substrate size and elevation were the most important factors in the analysis and were important on both CCA axes. Eigenvalues for the two CCA axes were 0.82 and 0.55 . It is important to note that these two variables act as surrogates for the group of variables associated with PC 1 (table 3 ).

The results of CCA indicate a gradient in species percentage abundances between species dominating the valley floor sites and species dominating the Sierra Nevada sites, particularly trout (fig. 3A). The central position of the TWINSPAN species group of
Sacramento pikeminnow and Sacramento sucker is consistent with the broad distribution of these species and the resulting co-occurrence with a variety of native and introduced species associated with the foothill and large river site groups. Similarly, smallmouth bass was broadly distributed but tended to be most abundant for species characteristic of the large river and agricultural drain groups.

The TWINSPAN agricultural drain and large river site groups are separated from the other groups on CCA axis 1 (fig. 3B). The TWINSPAN agricultural drain site group and the mountain site group are the extremes of the ordination. The foothill site group and large river site group are intermediate in the ordination

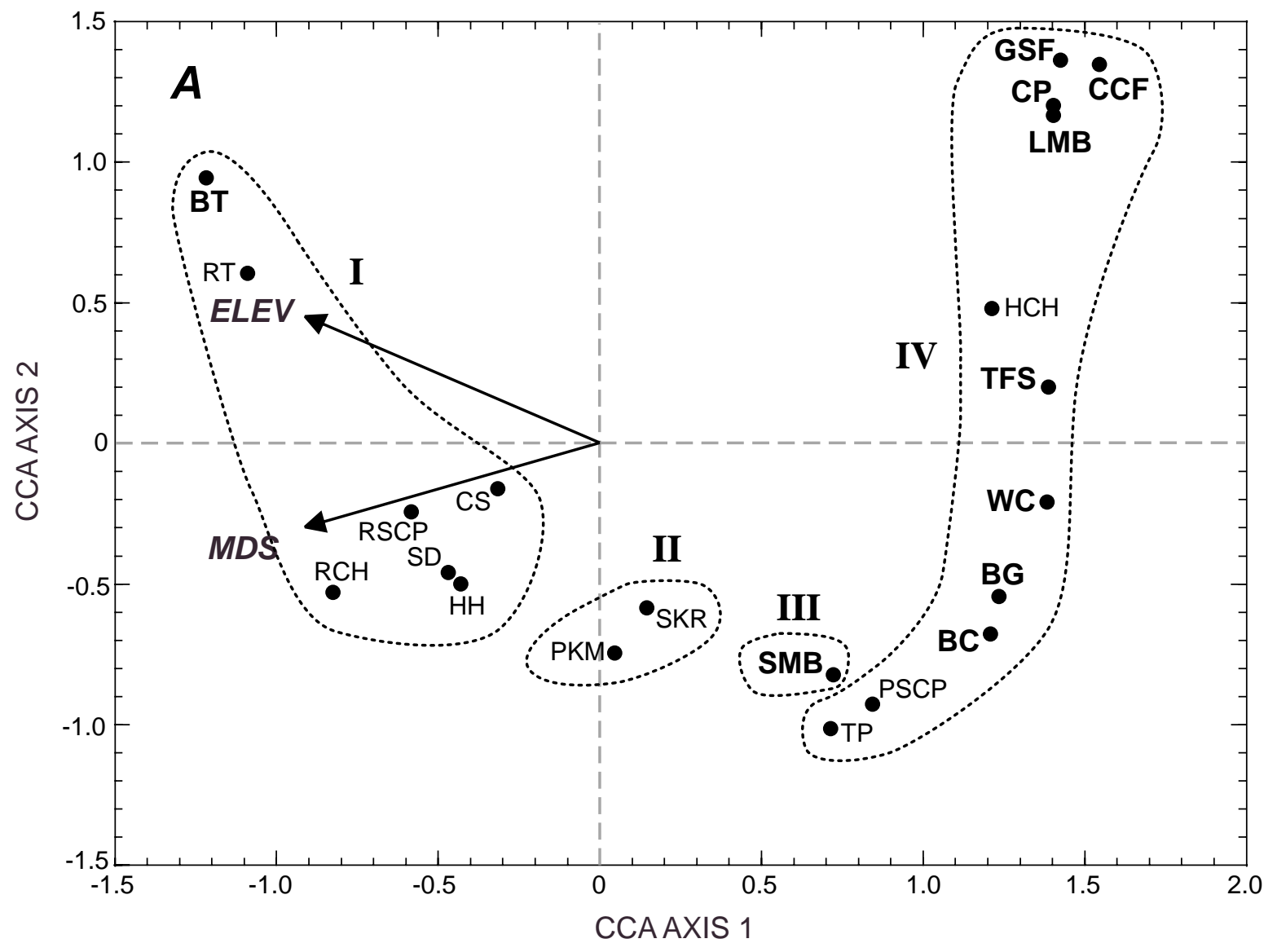

Figure 3. Plot of scores on the first two axes from the canonical correspondence analysis (CCA) for sampling sites in the Sacramento River Basin, California. A, Species scores (see table 2 for species codes). B, Site scores (see table 1 for site names and codes). In figure 3A, TWINSPAN species groups are enclosed by dashed lines. The arrows represent the correlation of the physical variables with the axes (MDS, mean dominant size; ELEV, elevation). Arrows parallel to an axis indicate a high correlation with the axis. Regular font indicates native species, and bold font indicates introduced species. In figure 3B, TWINSPAN sites groups are labeled and enclosed by dashed lines. The arrows represent the correlation of the physical variables with the axes (MSD is mean dominant substrate size and ELEV is elevation). Arrows parallel to an axis indicate a high correlation with the axis. 
space (fig. 3B). CCA axis 2 separated mountain sites from the foothill sites.

\section{Spatial and Annual Variation}

The first four DCA axes explained 35 percent of variance within the species data. The first two axes explained 17 and 8 percent of the variance, respectively. Visual inspection of the DCA site plot (fig. 4) and site scores indicate that there was little spatial or annual variation in fish community composition. The largest annual differences were at sites BU4, SACR, $\mathrm{FR}$, and CBD. The raw data indicate that the annual variation generally was associated with differences in percentage abundances rather than presence or absence of species. The variation in sampling methods for sites BU4 and SACR may have contributed to annual variability in numbers of fish observed; however, other sites where survey methods varied (BC2, BC4, BU6, and YR) showed low annual variability.

\section{Fish Community Metrics}

All metrics tested were statistically different among site groups (table 6). The percentage of native fish was lowest in the agricultural drain group. The number of native species and the percentage of intolerant fish also were lowest in the TWINSPAN agricultural drain group, but the number of native species was not statistically different from that of the mountain group. The number of tolerant species and the percentage of omnivorous fish were not statistically different between the TWINSPAN agricultural drain group and the large river group. The percentage of fish with external anomalies was highest in the TWINSPAN agricultural drain group and was significantly different from the percentage in the rest of site types sampled. The

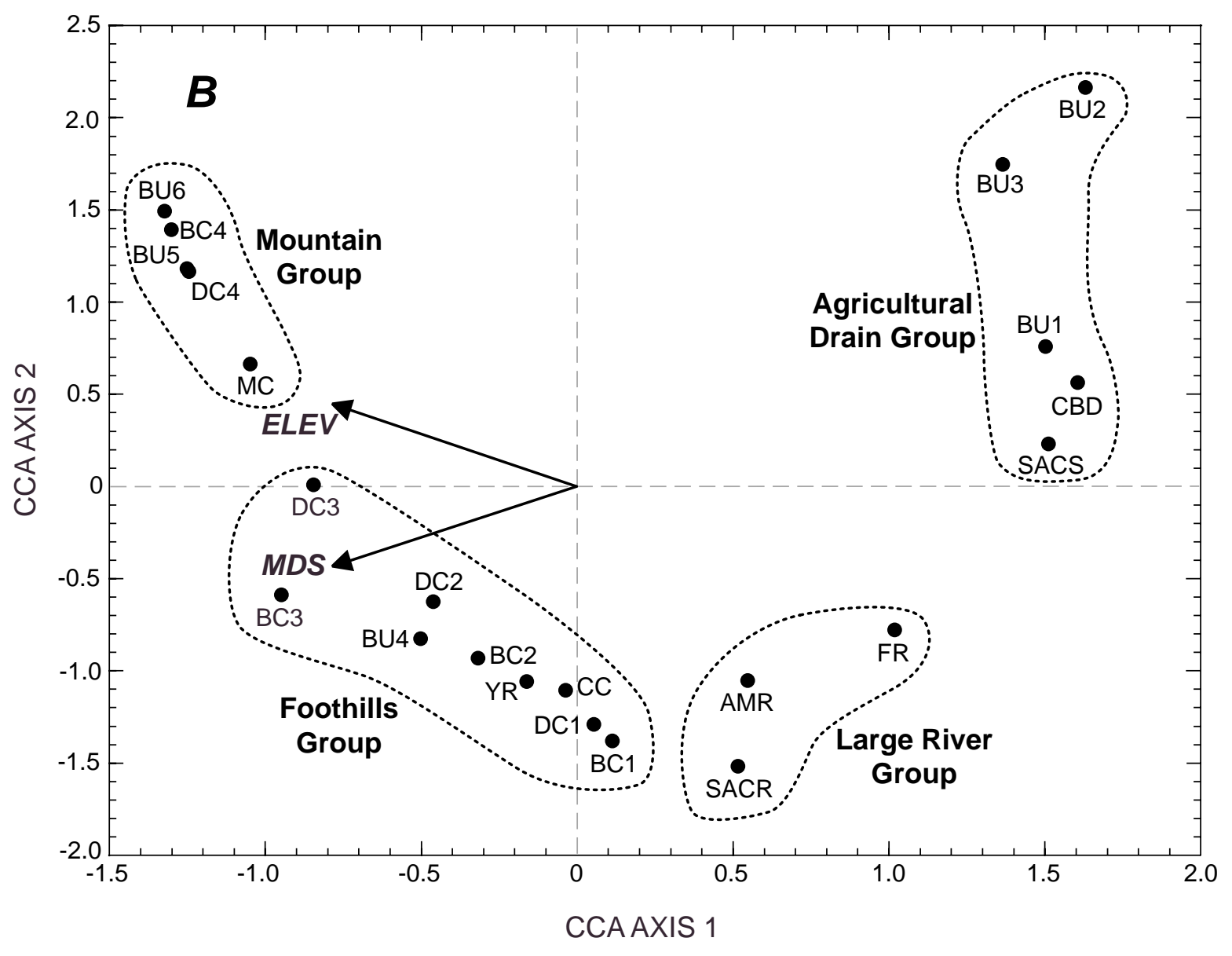

Figure 3. - Continued 
large river group was intermediate between the agricultural drain group and the foothill group.

\section{IM PLICATIONS FOR THE GREATER CENTRAL VALLEY}

In general, fish in streams in the Sacramento River Basin appeared to respond to a longitudinal gradient in physical environmental conditions; this result is consistent with that of previous but less geographically extensive studies of Central Valley fish (Moyle and Nichols, 1973; Moyle and others, 1982; and Brown, 2000). The percentage abundances of species and species assemblages at specific sites were related to environmental variables (fig. $3 A$ ). The mean values of a number of environmental variables were statistically different among site groups (table 4). The CCA ordination stressed elevation and mean dominant substrate size; these variables, particularly elevation, were largely acting as surrogates for an environmental gradient summarized by PC 1 (table 3). Substrate size was particularly important in separating the agricultural drain sites, which were dominated by sand and silt, from the other sites, which were dominated by gravel and cobbles.

Although introduced species were found at many of the sites sampled (table 2), they were most abundant

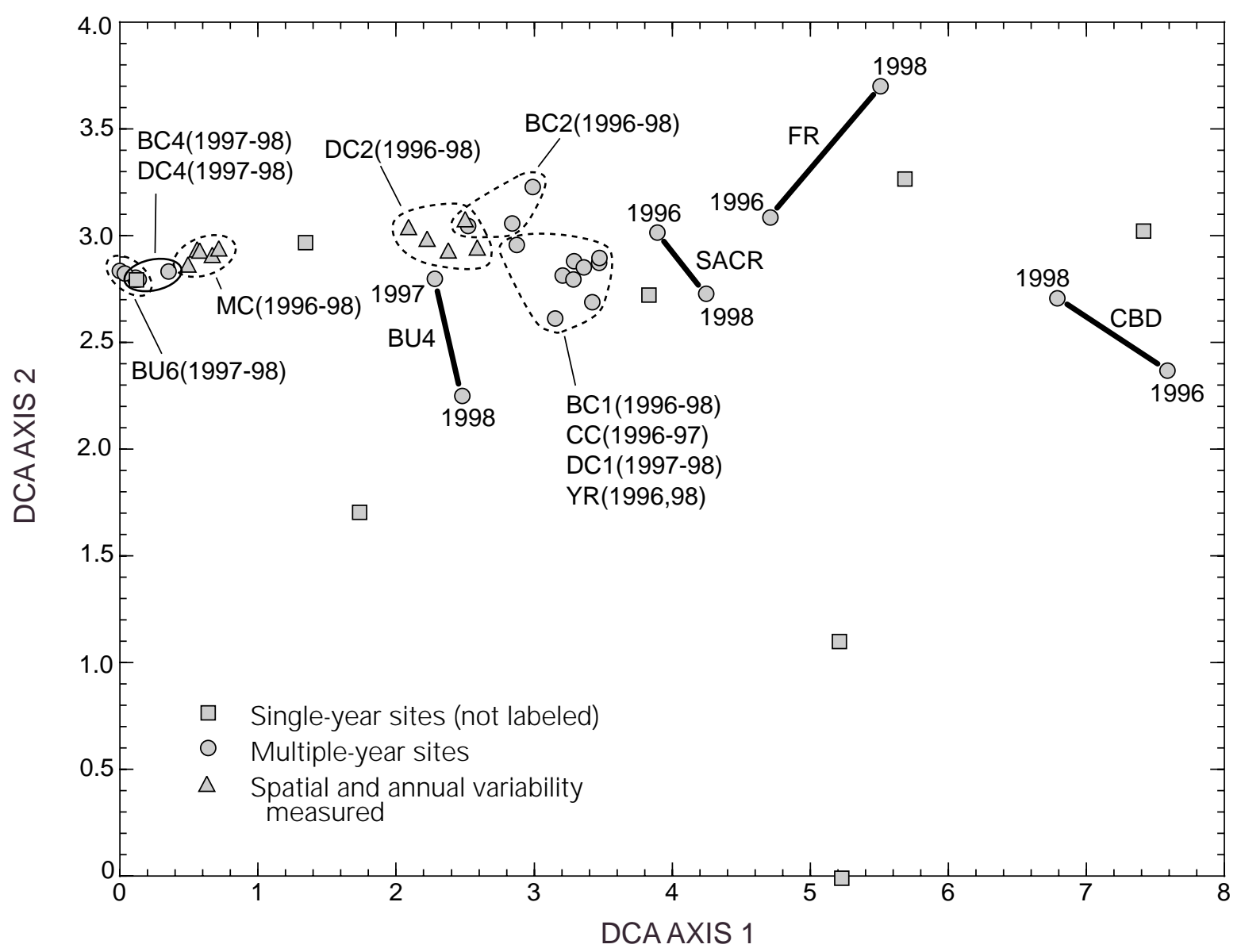

Figure 4. Plot of detrended correspondence analysis (DCA) site scores derived from fish species percentage-abundance data from sampling site in the Sacramento River Basin, California. Sites represented by open squares (not labeled) were only sampled once during the study; open circles were sampled during multiple years, and open triangles were sampled for both spatial and annual variation. Lines connect or enclose sites values for particular sites. Years are represented by the last two digits of the year. 
Table 6. Median and range of selected fish community metrics for TWINSPAN site groups in the Sacramento River Basin, Califomia

[See figure 3 for location of group sites. All metrics tested were significant at $p<0.05$ (Kruskal-Wallis one-way analysis of variance). TWINSPAN, two-way indicator species analysis. Values with different letters $\left({ }^{\mathrm{A}-\mathrm{C}}\right)$ indicate significant difference among site groups; values with the same letter indicate that the difference was not significant. Range of variable given in parentheses]

\begin{tabular}{|c|c|c|c|c|}
\hline \multirow[b]{2}{*}{ Fish community metrics } & \multicolumn{4}{|c|}{ TWINSPAN site group } \\
\hline & $\begin{array}{l}\text { Agricultural } \\
\text { drain group } \\
\text { (five sites) }\end{array}$ & $\begin{array}{l}\text { Large river } \\
\text { group } \\
\text { (three sites) }\end{array}$ & $\begin{array}{c}\text { Foothill } \\
\text { group } \\
\text { (nine sites) }\end{array}$ & $\begin{array}{l}\text { Mountain } \\
\text { group } \\
\text { (five sites) }\end{array}$ \\
\hline Percentage of native fish & $4^{\mathrm{A}}(1.4-42)$ & $81.7^{\mathrm{B}}(30.7-95.6)$ & $98^{\mathrm{B}}(87-100)$ & $72^{\mathrm{B}}(53-100)$ \\
\hline Number of native species & $1^{\mathrm{A}}(1-3)$ & $6^{\mathrm{B}}(5-9)$ & $5^{\mathrm{B}}(4-11)$ & $1^{\mathrm{A}}(1-2)$ \\
\hline Percentage of intolerant fish & $0^{\mathrm{A}}(0)$ & $25.4^{\mathrm{B}}(9.2-35)$ & $40.3^{\mathrm{B}}(1.6-76.7)$ & $100^{C}(100)$ \\
\hline Number of tolerant species & $3^{\mathrm{A}}(3-9)$ & $4^{\mathrm{A}}(2-4)$ & $0^{\mathrm{B}}(0-3)$ & $0^{\mathrm{B}}(0)$ \\
\hline Percentage of omnivorous fish & $7.7^{\mathrm{A}}(5-14)$ & $15.5^{\mathrm{A}}(3.4-25.6)$ & $31.8^{\mathrm{B}}(23.3-59.74)$ & $0^{\mathrm{C}}(0)$ \\
\hline Percentage of fish with anomalies & $13.6^{\mathrm{A}}(4-33)$ & $3.8^{\mathrm{B}}(2.7-11.2)$ & $0^{\mathrm{C}}(0-6.8)$ & $0^{\mathrm{C}}(0)$ \\
\hline
\end{tabular}

in agriculture drainage sites (table 2). In general, fish communities in the Sacramento River Basin are still dominated by native species (table 6); however, some native species are now extinct (thicktail chub, Gila crassicauda), locally extirpated (Sacramento perch, Archoplites interruptus), or reduced in abundance (for example, Sacramento splittail, chinook salmon, or steelhead rainbow trout).

In contrast, introduced species dominated Central Valley streams in the San Joaquin River Basin from 1993 to 1995. The San Joaquin River mainstem was dominated by non-native species rarely encountered in the Sacramento River system-specifically, threadfin shad, red shiner, fathead minnow, and inland silverside (Brown, 2000). Largemouth bass, redear sunfish, bluegill, white catfish, and channel catfish characterized the lower sections of the large tributaries of the San Joaquin River (Brown, 2000). Many species captured from the San Joaquin River (Brown, 2000) were present in the Sacramento River drainage, but they dominated only the most disturbed habitats, such as the agricultural drains. The agricultural drains appeared to be highly stressful environments given the predominance of tolerant fish species and the high percentage of fish with anomalies (table 6).

It is important to note that the study by Brown (2000) was done at the end of a 6-year drought, which may have altered the distribution patterns of resident fishes characteristic of less stressful conditions. Although the native fish of the Central Valley have evolved to adapt to natural periods of extreme drought, the additional effects of human activities and introduced species may have more severe effects on native fish distribution (Moyle, 1976a). For example, Saiki
(1984) observed native species in the mainstem of the San Joaquin River more often than did Brown (2000) but still at low abundances.

Studies in California (Moyle and Light, 1996a,b; Baltz and Moyle, 1993) and elsewhere (Minkely and Meffe, 1987; Meffe, 1991) indicate that native species assemblages are resistant to invasion when natural flow conditions are maintained. A general comparison of total annual discharge between the Sacramento River Basin and San Joaquin River Basin over the duration of both the current study and that of Brown (2000) indicated that discharge of the Sacramento River Basin was nearly 10 times that of the San Joaquin River Basin. This difference may account for some of the differences seen in fish assemblages between the two studies; however, differences in water-management practices between the two systems may have had a greater effect on fish community structure. In the San Joaquin River drainage, water captured in foothill reservoirs is generally diverted into canal systems, leaving little water in the streams. Additional diversions occur as streams flow through the San Joaquin Valley and as significant inputs of agricultural return water occur. As a result of these practices, the San Joaquin River system is characterized by lentic-like stream conditions. In the Sacramento River drainage, water is generally released into stream channels for downstream delivery rather than diverted; this results in more riverine-like conditions, although the timing and magnitude of flows may be altered from the natural flow regime.

The more riverine-like conditions of the Sacramento River Basin apparently support the native species and discourage introduced species. Relative abundances of fish species in the Sacramento River 
Basin appear to be a function of abiotic processes. Native fish have evolved to adapt to seasonal fluctuations in water temperature and stream discharge. In contrast, the introduced species in the drainage, with the exception of smallmouth bass and brown trout, tend to be warm-water species ill-equipped to sustain substantial populations under current conditions of fluctuating high discharges of cold water (Baltz and Moyle, 1993; Brown and Moyle, 1993; Moyle and Light, 1996 a, b). Physiological and behavioral responses of species to temperature and flow conditions are strong factors responsible, in part, for structuring native California stream fish assemblages (Baltz and others, 1982, 1987; Cech and others, 1990).

\section{Spatial and Annual Variation}

Spatial and annual variability in fish community structure was minimal (fig. 4). The relative abundance of species varied rather than the presence or absence of species that has been observed in other systems (Rahel, 1990). Sites MR and DC2, for which three adjacent reaches were sampled, showed little spatial variation in species composition and relative abundance (fig. 4).

Similar results for fish community structure were obtained at sites (BC2, BC4, BU4, BU6, SACR, and YR) where sampling methodology varied during the 1998 sampling (fig. 4). The raw data for these sites indicate little or no variation in species composition and that most annual variation was in the relative abundance of each species. For sites with less-diverse species assemblages (BC4 and BU6), the variation resulting from different sampling methods was minimal. For sites with intermediate species richness (BC2, BU4, and YR), the variation in community structure appeared to be greatest in riffle-oriented species, such as sculpins and dace. For SACR, a site with relatively high species richness, the variation in community structure related to 1996 and 1998 sampling methods appeared to be similar to annual variation observed at a similar site, Feather River at Nicholas (FR). Clearly, it is desirable to use the same sampling methodology throughout a study, but in this case the changes do not seem to have affected the results to a significant degree.

\section{Fish Community Metrics}

Differences among site groups for the fish community metrics tested (table 6) indicate that an IBI could be developed for streams of the Sacramento River Basin and potentially for the greater Central Valley. Metrics for the agricultural drainage sites were clearly different from those of the other sites. Moreover, the assemblages and corresponding metric values for the agricultural drainage sites were very similar to those observed in the lower San Joaquin River drainage (Brown, 2000).

The metrics based on percentages of native fish, percentage of intolerant fish, number of tolerant species, and percentage of fish with external anomalies showed similar responses associated with changes in environmental quality and TWINSPAN site groupings. The number of native species did not perform well as a metric because of the small number of species at mountain sites. This metric might be useful if restricted to more species-rich, lower elevation sites.

The percentage of omnivorous fish was a poor metric in both the Sacramento and San Joaquin River Basins. A high value for the percentage of omnivorous fish is usually viewed as an indicator of poor environmental quality (Karr, 1981; Fausch and others, 1984; Hughes and Gammon, 1987). In the San Joaquin River Basin, this metric inaccurately depicted sites as having poor environmental quality owing to high abundances of the native omnivore Sacramento sucker (Brown, 2000). A similar result was obtained for the current study (table 6) because the Sacramento sucker was the most widely distributed species observed in the Sacramento River drainage. This metric might be useful for Central Valley streams if only the percentage of nonnative omnivores is assessed.

A fundamental problem for developing an IBI for the San Joaquin River drainage was the lack of adequate reference conditions in the lower San Joaquin River drainage (Brown, 2000). Because the Sacramento and San Joaquin River systems had similar predevelopment fish faunas (Moyle, 1976b), the Sacramento River Basin may serve the function of reference or least impacted conditions for the San Joaquin River Basin. In addition, native species remain relatively abundant in the mainstem of the Sacramento River and many tributaries. Water-year (discharge) variations among years can have substantial effects on the native fish abundances in Central Valley streams 
(Baltz and Moyle, 1993; Brown, 2000) and in Mediterranean-climate streams in general (Elvira, 1995; Moyle, 1995; Godinho and others, 1997). Consideration of these flow variations must be taken into account when attempting to formulate an IBI for Central Valley streams.

\section{Conservation Implications}

Native fish species remain widely distributed and abundant in the Sacramento River Basin, especially in comparison with the San Joaquin River drainage in the southern Central Valley. The main exception is the agricultural drains where introduced species are dominant. On the basis of historical records and archeological evidence (Schulz and Simmons, 1973; Moyle, 1976b), most of the native species are still present, with the exception of Sacramento blackfish (Orthodon macrolepidotus), which were not observed; the locally extirpated Sacramento perch (Archoplites interruptus); and the extinct thicktail chub (Gila crassicauda). However, the presence of introduced species at low abundances throughout the basin is a concern. Changes in water management in response to climatic changes or changes in agricultural or urban needs could result in environmental conditions favoring introduced species. The invasion of the Foothill ecoregion by introduced species, especially smallmouth bass, represents a serious challenge for conservation of native California stream fish assemblages (Moyle and Nichols, 1974; Brown and Moyle 1993) and protection for some of the few relatively undisturbed spawning and rearing grounds for anadromous salmonids remaining in the Central Valley (Yoshiyama and others, 1998). The growing population of California [projected to reach 42.4 million by the year 2010 (California Institute, 1999)] combined with the natural water-resource limitations of a Mediterranean-type climate will severely tax the water resources of the state. Accordingly, it is imperative to consider the potential effects of future management strategies on the native fish communities of the Central Valley. Successful conservation of native fish fauna of the Central Valley requires competent management of the rivers and upland streams, not merely as water conveyance channels but also as living ecosystems (Nehlsen and others, 1992; Bottom, 1995; Yoshiyama and others, 1998).

\section{SUM MARY}

A total of 36 taxa of fish were captured during sampling of 22 sites from 1996 to 1998 in the Sacramento River Basin, California. Only 13 taxa were native to the basin. Multivariate analysis of relative abundance data revealed four site groups characterized by different fish community structure. The distribution of fish species was correlated with the elevation of a sampling site and the mean dominant substrate size; elevation, however, was correlated with many waterquality and habitat variables. Four of the fish community metrics-percentage of native fish, percentage of intolerant fish, number of tolerant species, and percentage of fish with external anomalies-were responsive to environmental quality. In contrast, number of native species and percentage of omnivorous fish were not correlated with environmental quality. Fish community structure in the Sacramento River Basin is responsive to environmental gradients. Findings of this study have management implications for streams in the greater Central Valley, California.

\section{REFERENCES CITED}

Baltz, D.M., and Moyle, P.B., 1993, Invasion resistance to introduced fishes by a native assemblage of California stream fishes: Ecological Applications, v. 3, p. 246-255.

Baltz, D.M., Moyle, P.B., and Knight, N.J., 1982, Competitive interaction between benthic stream fishes, riffle sculpin, Cottus gulosus, and speckled dace, Rhinichthys osculus: Canadian Journal of Fisheries and Aquatic Sciences, v. 39, p. 1502-1511.

Baltz, D.M., Vondracek, Bruce, Brown, L.R., and Moyle, P.B., 1987, Influence of temperature on microhabitat choice by fishes in a California stream: Tranactios of the American Fisheries Society, v. 116, p. 12-20.

Bottom, D.L., 1995, Restoring salmon ecosystems, Myth and reality: Resource Management Notes, v. 64, p. $37-40$.

Brown, L.R., 2000, Fish communities and their associations with environmental variables, lower San Joaquin River drainage, California: Environmental Biology of Fishes, v. 57, p. 251-269.

Brown, L.R., and Moyle, P.B., 1993, Distribution, ecology, and status of fishes of the San Joaquin drainage, California: California Department of Fish and Game, v. 79, p. 96-114.

California Institute, 1999, California Institute population data: An online source for information on California 
and federal policy. URL: http://www.calinst.org/ datapages/popproj.html/

Cech, J.J., Jr., Mitchell, S.J., Castleberry, D.T., and McEnroe, M., 1990, Distribution of California stream fishes: influence of environmental temperature and hypoxia: Environmental Biology of Fishes, v. 29, p. 95-105.

Elvira, B., 1995, Native and exotic freshwater fishes in Spanish river basins: Freshwater Biology, v. 33, p. 103-108.

Fausch, K.D., Karr, J.R., and Yant, P.R., 1984, Regional application of an index of biotic integrity based on stream fish communities: Transactions of American Fisheries Society, v. 113, p. 39-55.

Fishman, M.J., and Friedman, L.C., eds., 1989, Methods for determination of inorganic substances in water and fluvial sediments: U.S. Geological Survey Techniques of Water-Resources Investigations, book 5, chap. A1, $545 \mathrm{p}$.

Gard, M.F., 1994, Biotic and abiotic factors affecting native stream fishes in the South Fork Yuba River, Nevada County, California: Davis, California, University of California, Ph. D. dissentation, 174 p.

Gauch, H.G. Jr., 1982, Multivariate analysis in community ecology: New York, Cambridge University Press, 298 p.

Godinho, F.N., Ferreira, M.T., and Cortes, R.V., 1997, Composition and spatial organization of fish assemblage in the lower Guadiana basin, Southern Iberia: Ecology of Freshwater Fishes, v. 6, p. 134-143.

Hill, M.O., 1979, TWINSPAN: a FORTRAN program for arranging multivariate data in an ordered two-way table by classification of the individuals and attributes: Ithaca, N.Y., Cornell University, Section of Ecology and Systematics, $90 \mathrm{p}$.

Hill, M.O., and Gauch, H.G., 1980, Detrended correspondence analysis, an improved ordination technique: Vegetatio, v. 42, p. 47-58.

Hughes, R.M., and Gammon, J.R., 1987, Longitudinal changes in fish assemblages and water quality in the Willamette River, Oregon: Transactions of the American Fisheries Society, v. 116, p. 196-209.

Jennings, M.R., and Saiki, M.K., 1990, Establishment of red shiner, Notropis, lutrensis, in the San Joaquin Valley, California: California Department of Fish and Game, v. 76, p. 46-57.

Jongman, R.H.G., ter Braak, C.J.F, and Tongeren, O.F.R., 1987, Data analysis in community and landscape ecology: Cambridge University Press, 299 p.

Kahrl, W.L., Bowen, W.A., Brand, S., Shelton, M.L., Shelton, D.L., and Ryan, D.A., 1978, The California water atlas: Sacramento, California, The governor's office of planning and research, $118 \mathrm{p}$.
Karr, J.R., 1981, Assessment of biotic integrity using fish communities: Fisheries, v. 6, p. 21-27.

Meador, M.R., Hupp, C.R., Cuffney, T.E., and Gurtz, M.E., 1993a, Methods for characterizing stream habitat as part of the National Water-Quality Assessment Program: U.S. Geological Survey Open-File Report 93-408, 48 p.

1993b, Methods for sampling fish communities as part of the National Water-Quality Assessment Program: U.S. Geological Survey Open-File Report 93-104, $40 \mathrm{p}$.

Meffe, G.K., 1991, Failed invasion of a Southeastern black water stream by bluegill: implications for conservation of native communities: Transactions of the American Fisheries Society, v. 120, p. 333-338.

Minkely, W.L., and Meffe, G.K., 1987, Differential selection by flooding in stream fish communities of the arid American Southwest, in Matthews, W.J., and Heins, D.C., eds., Community and evolutionary ecology of North American stream fishes: Norman, Okla., University of Oklahoma Press, p. 93-104.

Mount, J.F., 1995, California rivers and streams: the conflict between fluvial process and land use: University of California Press, Berkeley, Calif., 359 p.

Moyle, P. B., 1976a, Fish introductions in California: history and impact of native fishes: Biological Conservation, v. 9, p. 101-118. 1976b, Inland fishes of California: Berkeley, Calif., University of California Press, 405 p.

1995, Conservation of native freshwater fishes in the mediterranean-type climate of California, USA: A review: Biological Conservation, v. 72, p. 721-279.

Moyle, P. B., and Light, T., 1996a, Biological invasions of freshwater: empirical rules and assembly theory: Biological Conservation, v. 78, p. 149-162.

, 1996b, Fish invasions in California: Do abiotic factors determine success?: Ecology, v. 77, p. $1666-1670$.

Moyle, P.B., and Nichols, R.D., 1973, Ecology of some native and introduced fishes of the Sierra Nevada foothills in central California: Copeia, v. 1973, p. 978-990. 1974, Decline of native fish fauna of the Sierra Nevada foothills, central California: American Midland Naturalist, v. 92, p. 72-83.

Moyle, P.B., and Randall, P.J., 1998, Evaluating the biotic integrity in the Sierra Nevada, California: Conservation Biology, v. 12, no. 6, p. 1318-1326.

Moyle, P.B., Smith, J.J., Daniels, R.A., Taylor, T.L., Price, D.G., and Baltz, D.M., 1982, Distribution and ecology of stream fishes of the Sacramento-San Joaquin Drainage system, California: Berkeley, Calif., University of California Press, 256 p. 
Nehlsen, W., Lichatowich, J.A., and Williams, J.E., 1992, Pacific salmon and the search for sustainability: Renewable Resources Journal, v. 10, p. 20-26.

Omernik, J.M., 1987, Ecoregions of the conterminous United States: Annals of the Association of American Geographers, v. 77, p. 118-125.

Rahel, F.J., 1990, The hierachical nature of community persistence: a problem of scale: American Naturalist, v. 136 , no. 3 , p. 328-344.

Reisner, M., 1986, Cadillac Desert: New York, VikingPenguin, $582 \mathrm{p}$.

Saiki, M.K., 1984, Environmental conditions and fish faunas in low elevation rivers on the irrigated San Joaquin Valley floor, California: California Department of Fish and Game, v. 70, p. 145-157.

Schulz, P.D., and Simmons, D.D., 1973, Fish species diversity in a prehistoric central California Indian midden: California Department of Fish and Game, v. 59, p. 107-113. ter Braak, C.J.F., 1986, Canonical correspondence analysis: a new eigenvector method for multivariate direct gradient analysis: Ecology, v. 67, p. 1167-1179.

, 1987, CANOCO: a FORTRAN program for canonical community ordination by (partial) (detrended) (canonical) correspondence analysis, principal component analysis and redundancy analysis: Wageningen, The Netherlands, TNO Institute of Applied Computer Science.

U.S. Geological Survey, 1986, Land use and land cover digital data from 1:250,000 and 1:100,000-scale maps: U.S. Geological Survey, National Mapping Program Technical Instructions, Data Users Guide 4, 36 p.

Yoshiyama, R.M., Fisher, F.W., and Moyle, P.B., 1998, Historical abundance and decline of Chinook salmon in the central valley region of California: North American Journal of Fisheries Management, v. 18, p. 487-521. 